\title{
Associations of Obesity with Linear Growth and Puberty
}

\author{
Shlomit Shalitin ${ }^{a, b}$ Galia Gat-Yablonski ${ }^{b, c}$ \\ aNational Center for Childhood Diabetes, Schneider Children's Medical Center of Israel, The Jesse Z and Sara \\ Lea Shafer Institute for Endocrinology and Diabetes, Petach Tikva, Israel; bSackler Faculty of Medicine, Tel Aviv \\ University, Tel Aviv, Israel; ' Felsenstein Medical Research Center, Petach Tikva, Israel
}

\section{Keywords \\ Obesity · Growth · Puberty · Leptin · Adiponectin · Insulin}

\begin{abstract}
Background: The prevalence of obesity in childhood has increased dramatically in recent decades with increased risk of developing cardiometabolic and other comorbidities. Childhood adiposity may also influence processes of growth and puberty. Summary: Growth patterns of obesity during childhood have been shown to be associated with increased linear growth in early childhood, leading to accelerated epiphyseal growth plate (EGP) maturation. Several hormones secreted by the adipose tissue may affect linear growth in the context of obesity, both via the growth hormone IGF-1 axis and via a direct effect on the EGP. The observation that children with obesity tend to mature earlier than lean children has led to the assumption that the degree of body fatness may trigger the neuroendocrine events that lead to pubertal onset. The most probable link between obesity and puberty is leptin and its interaction with the kisspeptin system, which is an important regulator of puberty. However, peripheral action of adipose tissue could also be involved in changes in the onset of puberty. In addition, nutritional factors, epi-
\end{abstract}

genetics, and endocrine-disrupting chemicals are potential mediators linking pubertal onset to obesity. In this review, we focused on interactions of obesity with linear growth and pubertal processes, based on basic research and clinical data in humans. Key Message: Children with obesity are subject to accelerated linear growth with risk of impaired adult height and early puberty, with its psychological consequences. The data highlight another important objective in combatting childhood obesity, for the prevention of abnormal growth and pubertal patterns.

ㄷ) 2021 S. Karger AG, Base

\section{Introduction}

Obesity during childhood and adolescence remains one of the most important issues in global health. Over the past 4 decades, obesity in children of all ages has increased worldwide [1]. The prevalence of obesity varies according to racial, ethnic, and socioeconomic factors [2] and increases with advancing age [3]. Childhood obesity has been tracked into adulthood.

Pediatric obesity results from various factors, starting with genetic predispositions and the gestational environ- karger@karger.com

www.karger.com/hrp

Karger $\stackrel{2}{*}$
(C) 2021 S. Karger AG, Basel

Correspondence to:

Shlomit Shalitin, shomits2@ clalit.org.il 
ment, and progressing from early childhood through adolescence. Socioeconomic status and health literacy also affect obesity. However, the current obesity epidemic seems to be driven mainly by evolving food practices (increased energy-dense and ultraprocessed foods and sweetened beverages) [4] and reduced physical activity [5].

Obesity during childhood has important short- and long-term consequences. These include risks of diseases and disorders that previously occurred almost exclusively in adults, such as type 2 diabetes, hypertension, dyslipidemia, nonalcoholic fatty-liver disease, obstructive sleep apnea, and systemic low-grade inflammation [6-8]. In the long term, obesity during childhood increases risks of developing cardiovascular diseases and some cancers and premature death [9].

Several lines of evidence support the interplay of nutritional status, energy balance, and hormones in the regulation of growth and pubertal development. Frequently, children with obesity are taller for their age, with accelerated linear growth and advanced skeletal maturation, and tend to mature earlier than lean children [10].

Adipocytes are an active secretory tissue that release many endocrine and paracrine factors termed adipokines; these affect peripheral tissues and the central nervous system. Adipokines are involved in energy homeostasis [11], bone growth [12], and pubertal processes [13]. This review provides an overview of the complex interactions between obesity in childhood and the processes of linear growth and puberty, based on basic research and observational studies in humans.

\section{Obesity and Linear Growth}

\section{Growth in Offspring of Mothers with Obesity}

Intrauterine growth of the fetus is affected by placental function and by fetal and maternal factors. Preclinical animal studies and human translational studies suggest that increased chronic inflammation, oxidative stress, and insulin resistance related to maternal obesity create an intrauterine environment that can lead to altered fetal growth, with long-term "programmed" detrimental effects on the offspring [14].

The placenta is an important source of leptin, tumor necrosis factor (TNF)- $\alpha$, and interleukin (IL)- 6 . Placentas of pregnant women with obesity are characterized by enhanced infiltration of macrophages and expression of inflammatory markers [15]. An association is widely recognized of maternal obesity with fetal growth from as early as the second trimester of pregnancy [16] and with signifi-

Obesity and Linear Growth and Puberty cantly higher fat mass of the offspring [17]. Thus, the relatively increased proinflammatory cytokine production by the adipose tissue and placentas of women with obesity may amplify physiological adaptations in pregnancy, leading to increased availability of nutrients for the fetus.

Insulin sensitivity decreases by $50-60 \%$ during normal pregnancy; insulin resistance is even more marked in obese pregnancy [18]. Moreover, the relative inability of insulin to suppress whole-body lipolysis results in increased plasma free fatty acid (FFA) [19]. These processes substantially augment the energy available for transport to fetuses in pregnant women with obesity. The increased IL- 6 and TNF- $\alpha$ levels in the placentae of mothers with obesity have been suggested to increase amino acid transport to the fetus [20] and may also contribute to fetal overgrowth.

Leptin and adiponectin are 2 main cytokines released by white adipose tissue and involved in energy homeostasis. Secreted mainly from white adipose tissue, leptin signals the brain of the body's energy stores. In conjunction with other adipokines and hormones, leptin's action in the hypothalamus inhibits food intake and increases energy expenditure by increased thermogenesis. The soluble leptin receptor, the major circulating binding protein of leptin, is a potential marker of leptin sensitivity [21]. During pregnancy, leptin tends to increase [22], whereas adiponectin rises in early pregnancy and then decreases corresponding to decreased maternal insulin sensitivity [23].

A prospective longitudinal study demonstrated an association of prepregnancy obesity with higher leptin and lower soluble leptin receptor levels, suggestive of leptin resistance [24]. The upshot could be longer neonates in women with prepregnancy obesity. Adiponectin was inversely associated with neonatal length only in women with obesity.

Another prospective longitudinal study revealed longer bone lengths in fetuses born to women with rather than without obesity [16]. Such differences were apparent as early as 21 weeks' gestation and remained through delivery. Moreover, from 32 weeks' gestation, abdominal circumference was greater in fetuses of women with obesity than of normal weight. This suggests a role for maternal adipokine levels in the differences in fetal bone growth between women with and without obesity.

\section{Obesity and Linear Growth in the Postnatal Years} until Puberty

Postnatal linear growth is controlled by genetic, endocrine, and nutritional factors. Growth hormone $(\mathrm{GH})$ 
Fig. 1. Regulatory hormones affecting the process of linear growth in the constellation of obesity. GH, growth hormone; GHRH, growth hormone-releasing hormone; IGF-1, insulin-like growth factor; IGFBP-1/2, IGF-binding protein.

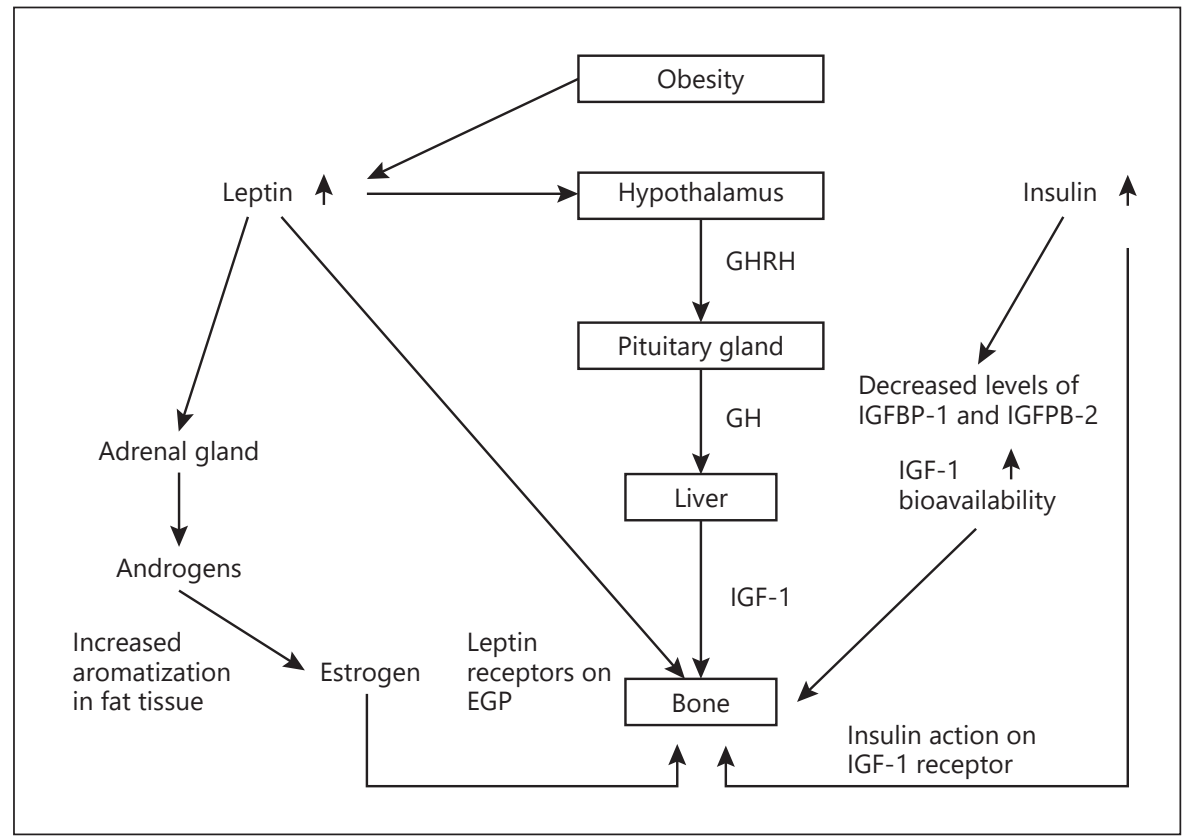

through insulin-like growth factor (IGF)-1 or by direct action on the epiphyseal growth plate (EGP) plays a major role in postnatal growth, together with thyroid hormones. Although adequate nutrition is essential for normal growth and children with obesity are usually taller than their normal-weight peers, they do not tend to attain taller height as adults [25]. Several regulatory hormones may affect linear growth in the constellation of obesity, as shown in Figure 1.

Long bones are formed through endochondral ossification, wherein a cartilage template is formed by condensed mesenchymal cells and later replaced by bone tissue. The process of endochondral ossification occurs within the EGP and is subjected to multiple regulatory mechanisms $[26,27]$.

The underlying mechanisms of obesity-related growth acceleration are still not fully resolved, and several factors secreted by adipocytes have been cited as possible mediators. Among them, insulin [28], leptin [13, 29], adiponectin [30], growth and differentiation factor (GDF)-5 [12], and estradiol [31] have demonstrated direct effects on EGP chondrocytes, as described below.

\section{The GH-IGF-1 Axis in Obesity}

An intact GH/IGF-1 axis is well recognized as the key regulator of somatic growth in humans. However, childhood obesity is characterized by normal or even accelerated linear growth during prepuberty despite abnormalities in the GH/IGF-1 axis. These abnormalities are main- ly characterized by reduced GH secretion with normal IGF-1 levels compared to normal-weight peers.

Analysis of the 24-h secretion of GH has confirmed a decreased spontaneous GH release in persons with obesity [32]. Adiposity acts as a negative determinant of the frequency and amplitude of GH secretory bursts. Accordingly, increased GH clearance leads to a lower GH halflife; this suggests a defect in both secretion and clearance [33]. Alterations in $\mathrm{GH}$ receptors and increased $\mathrm{GH}$ binding protein (GHBP) are consistent with these changes [34]. Therefore, children with obesity presumably present with normal growth despite reduced GH secretion. This is probably due to the combination of increased levels of total GHBP and the GH-GHBP complex that enable achieving normal production and bioavailability of IGF-1 [35].

Children with obesity also display blunted or absent responses to known GH stimuli, including fasting, exercise, and pharmacological stimulation [36]. Significant weight loss results in recovery of basal and stimulated GH release [37]. This indicates that metabolic alterations associated with weight gain precipitate low GH output, and these changes are reversible.

IGFs (IGF-1 and IGF-2) are involved in growth regulation [38]. In obesity, despite low GH values, IGF-1 levels are usually normal. This leads to the hypothesis that free elevated IGF-1 suppresses GH release. Studies in prepubertal children also support IGF-1's role in childhood obesity. These report increased GH sensitivity using an 
Table 1. Main functions of hormones/adipokine mediators in growth and puberty

\begin{tabular}{|c|c|c|c|}
\hline $\begin{array}{l}\text { Hormones/ } \\
\text { adipokines }\end{array}$ & Impact on growth & Impact on puberty & $\begin{array}{l}\text { Levels in } \\
\text { obesity }\end{array}$ \\
\hline Insulin & $\begin{array}{l}\text { Decreases IGFPB1 and increases levels of total and free IGF-1 } \\
\text { Increases action on the IGF-1 receptor [54] and the IR [59] } \\
\text { Increases chondrocyte proliferation and differentiation [28, 56, 57] } \\
\text { Accelerates linear growth and bone maturation with earlier EGP } \\
\text { closure [104] }\end{array}$ & $\begin{array}{l}\text { Stimulates GnRH and LH secretion }[143,144] \\
\text { Stimulates ovarian and adrenal steroidogenesis [145] } \\
\text { (increases 5 } \alpha \text {-reductase and } 21 \text {-hydroxylase activity and } \\
\text { lowers } 11 \beta \text { HSD1 activity) [154] } \\
\text { Reduces SHBG and increases sex steroid bioavailability [82] } \\
\text { May cause premature pubertal onset and premature } \\
\text { adrenarche }[144,145]\end{array}$ & $\uparrow$ \\
\hline Leptin & $\begin{array}{l}\text { Stimulates spontaneous GH secretion and the GH response to } \\
\text { GHRH [68] } \\
\text { Stimulates EGP cartilage proliferation and differentiation [76-78] } \\
\text { Augments aromatase mRNA expression and estrogen receptor } \\
\text { gene expression in chondrocytes [99] } \\
\text { Accelerates bone maturation, with earlier epiphyseal closure }\end{array}$ & $\begin{array}{l}\text { Stimulates secretion of kisspeptin and activates the HPG } \\
\text { axis and accelerates GnRH secretion }[126] \\
\text { Increases gonadotropin secretion }[131] \\
\text { Increases sex hormone secretion }[132,133] \\
\text { Increases synthesis of adrenal androgens [138] } \\
\text { Accelerates pubertal onset }\end{array}$ & $\uparrow$ \\
\hline Ghrelin & Increases $\mathrm{GH}$ secretion & & $\downarrow$ \\
\hline Adiponectin & $\begin{array}{l}\text { Increases chondrocyte proliferation and differentiation, } \\
\text { proteoglycan synthesis, and matrix mineralization [64] }\end{array}$ & $\begin{array}{l}\text { Inhibits secretion of kisspeptin and GnRH and release of } \\
\mathrm{LH} \text {, thereby inhibiting puberty onset }[140,141]\end{array}$ & $\downarrow$ \\
\hline GDF-5 & Regulates cartilage cell differentiation and proliferation $[85,86]$ & & $\uparrow$ \\
\hline $\begin{array}{l}\text { Estrogen/ } \\
\text { androgens }\end{array}$ & $\begin{array}{l}\text { Estrogen increases EGP maturation and fusion [95-97] } \\
\text { Increases aromatization in adipose tissue, of androgens into } \\
\text { estrogens, with accelerated growth and accelerated epiphyseal } \\
\text { fusion [96] }\end{array}$ & $\begin{array}{l}\text { Increased androgen concentrations enhance GnRH } \\
\text { secretion, possibly leading to earlier pubertal onset [150] }\end{array}$ & $\uparrow$ \\
\hline
\end{tabular}

EGP, epiphyseal growth plate; GH, growth hormone; GHRH, growth hormone-releasing hormone; GDF-5, growth and differentiation factor; GnRH, gonadotropin-releasing hormone; HPG, hypothalamic-pituitary-gonadal; HSD, 113beta-hydroxysteroid dehydrogenase; IGF-1, insulin-like growth factor; IGFPB1, insulin-like growth factor-binding 1; LH, luteinizing hormone; SHBG, sex hormone-binding globulin. The numbers in the brackets denote the relevant references.

IGF generation test [39] and a correlation of IGF-1 levels with longitudinal growth in limb length and height [40].

Ghrelin is an endogenous GH-releasing peptide produced predominantly in the stomach, which acts on GH secretagogue receptors and as an orexigenic factor. Fasting increases and food intake decreases plasma ghrelin levels. Ghrelin is also known to stimulate insulin secretion [41]. Ghrelin levels are lower in children with obesity than with normal weight [42]; the levels are proportional to the degree of insulin resistance [43]. The feeding regulatory role of the ghrelin-GH axis was investigated in 2 studies that used a mouse model of isolated GH deficiency due to targeted GH-releasing hormone (GHRH) gene knockout (GHRHKO). The first study [44] demonstrated that isolated GH deficiency due to targeted ablation of the GHRH gene was associated with increased relative subcutaneous and intra-abdominal fat mass and higher food consumption that was not related to changes in circulating leptin. Adiponectin and visfatin mRNA levels were decreased in both intra-abdominal and subcutaneous fat.

Obesity and Linear Growth and Puberty
The second study [45] evaluated the effects of intracerebroventricular ghrelin administration in mice homozygous for the GHRHKO allele (-/ - ) and heterozygous (+/-) control animals. Vehicle-treated GHRHKO mice showed greater food intake than heterozygotes; this was associated with increased circulating ghrelin levels. GHRHKO (-/-) mice showed elevated hypothalamic levels of neuropeptide Y (NPY) and agouti-related peptide (AgRP) mRNAs and decreased mRNA levels of corticotropin-releasing hormone $(\mathrm{CRH})$. Ghrelin treatment significantly augmented food intake in both genotypes, but the relative increase compared to vehicle-treated animals was higher in $-/-$ than $+/-$ mice. In the hypothalamus, ghrelin increased AgRP and decreased $\mathrm{CRH}$ gene expression only in heterozygous mice and induced a significant reduction in proopiomelanocortin mRNA levels in $-/-$ mice. Thus, dysregulation of the ghrelin-GHRH-GH axis in GHRHKO mice could explain the increased feeding secondary to elevated circulating levels of ghrelin. Moreover, the obesogenic phenotype is likely mediated by elevated

Horm Res Paediatr 2022;95:120-136 
NPY and AgRP and by decreased CRH gene expression in the hypothalamus.

Relations of adipose tissue with GH secretion are complex. Obesity induces hyperinsulinemia, hypoadiponectinemia, and hyperleptinemia; reduces serum ghrelin; and increases FFA levels, thereby suppressing GH secretion from the pituitary [46]. GH can contribute to insulin resistance that may develop when the caloric supply exceeds demand. Therefore, the reduced GH secretion occurring with obesity may be an adaptive phenomenon that prevents insulin resistance [47]. Hypotheses of how obesity-associated hyperinsulinemia may suppress $\mathrm{GH}$ production include direct pituitary action on GH synthesis and release [48] and indirect action by (1) modulating hypothalamic function, (2) altering IGF-I availability, and (3) suppressing circulating ghrelin levels [49].

\section{GH-Independent Growth in Obesity}

Since children with obesity continue to grow despite their low levels of $\mathrm{GH}$, their growth seems mainly GH independent. In some clinical conditions, normal growth persists or even accelerates in the presence of low GH serum levels. This "growth without GH" phenomenon has been observed in children with GH deficiency after surgery for craniopharyngioma, and their accelerated growth is associated with marked hypothalamic obesity. However, also children with exogenous obesity frequently show tall stature for their age, associated with accelerated bone age secondary to accelerated EGP maturation. This phenomenon can be explained by insulin resistance with hyperinsulinemia [50], bioactive but nonimmunoreactive GH [51], or increased levels of free IGF-1 [52] or of another unidentified "circulating factor" that stimulates growth independent of GH. The main functions of hormones/adipokine mediators in growth are presented below and summarized in Table 1.

\section{Insulin}

Insulin and IGF act through similar tyrosine kinase receptors [53]. Thus, in obesity, the increased insulin levels due to insulin resistance apparently increase insulin action on the IGF-1 receptor [54]. Indeed, in rats, the systemic injection of insulin has been shown to induce body growth [55].

The effect of insulin on EGP chondrocytes has been intensively studied. Adding insulin to cultured whole fetal metatarsal bones stimulated metatarsal linear growth in a concentration-dependent fashion [28]. In- sulin increased the metatarsal EGP proliferative and hypertrophic zone heights. Adding insulin to the medium of cultured chondrocytes isolated from metatarsal EGPs significantly increased cell proliferation and differentiation compared to untreated chondrocytes. Several in vitro studies have demonstrated stimulatory effects of insulin on chondrocyte proliferation $[56,57]$ and chondrocyte differentiation [28, 56, 57]. Additionally, insulin was shown to modulate liver GH receptor expression [55], decrease circulating IGFBP-1 levels, and stimulate IGF-1 mRNA expression in cultured hepatocytes [58] even in the absence of GH. These findings support a growth-promoting effect of hyperinsulinemia through increased circulating levels of total and free IGF-1.

In mice [28], a high-fat diet (HFD) led to greater body and tibial growth than did standard chow, concomitant with increased levels of serum insulin, IGF-1, leptin, and FFA. Administration of pioglitazone, an insulin sensitizer, to the HFD-fed mice led to lower body growth, tibial growth, and serum insulin levels; however, serum levels of IGF-1, IGFBP-1, IGFBP-3, leptin, and FFA were not significantly reduced [28]. HFD-fed mice also exhibited greater expression of phosphorylated, active, insulin receptor (p-IR) than did the mice fed with standard chow, but not in those treated with pioglitazone [28]. The same research team created transgenic mice with the IR gene ablated only in chondrocytes and exposed them to HFD. In the control mice, tibial length and whole EGP proliferative and hypertrophic zone heights of HFD-fed mice were all greater than in standard-diet-fed mice. In contrast, the effect of the HFD on the IR knockout (IR-KO) mice was significantly smaller. The tibial whole EGP and the proliferative and hypertrophic zone height were significantly greater in HFD control mice than in HFD IRKO. In both lines, HFD led to greater serum insulin, leptin, and IGF-1 levels [59]. These findings indicate that the growth acceleration caused by HFD in rodents is due to insulin resistance-related hyperinsulinemia, by direct activation of the IR in the EGP.

Additionally, in cultured chondrocytes transfected with small interfering RNA, to selectively silence IR expression, the effects of insulin on cell proliferation and differentiation were completely abolished. This supports an IR-mediated regulatory role for insulin on skeletal growth and EGP chondrogenesis [28]. Thus, insulin resistance and hyperinsulinemia are related to accelerated skeletal growth and EGP chondrogenesis [59].

In humans, the anabolic effect of insulin has mainly been described in small-for-gestational-age infants, in 
whom increased insulin secretion was found to be associated with increased catch-up linear growth, transiently followed by an increased rate of obesity [60]. Thus, insulin may contribute to increased linear growth in simple obesity in postnatal life.

\section{Adiponectin}

Adiponectin is secreted predominantly by differentiated adipocytes and involved in energy homeostasis [61]. Its level is reduced in adipose tissue of obese and diabetic mice and humans but restored to normal levels following weight loss [62].

Adiponectin and its receptors, AdipoR1 and AdipoR2, were expressed during chondrogenic differentiation of the mouse ATDC5 cell line, in an in vitro model of chondrogenesis [63]. However, data regarding the role of adiponectin in linear growth are conflicting. One study showed that adiponectin increased chondrocyte proliferation and differentiation, proteoglycan synthesis, and matrix mineralization, as reflected by upregulation of the expression of type II collagen, aggrecan, Runx2, and type $\mathrm{X}$ collagen, a unique marker of hypertrophic chondrocytes, and the activities of matrix metallopeptidase 9 and alkaline phosphatase [64]. However, a study in transgenic mice overexpressing human adiponectin in the liver found no effect of enhanced serum adiponectin levels on the length of long bones. This was despite increased bone volume and osteoblast activity [65].

\section{Leptin}

In humans, elevated serum leptin levels were found to be concomitant with central resistance to circulating leptin in simple obesity [66]. Leptin seems to mediate accelerated growth in the context of obesity [67].

Leptin receptors are expressed in hypothalamic nuclei known to be involved in GH regulation [68]. Leptin has a potent stimulatory action on both spontaneous pulsatile $\mathrm{GH}$ secretion and the GH response to GHRH [68]. Thus, leptin may be a critical hormonal signal of nutritional status in the neuroendocrine regulation of $\mathrm{GH}$ secretion.

In leptin-deficient ob/ob mice, leptin administration corrected metabolic abnormalities and also led to significantly increased femoral length $[69,70]$. A recent study showed that chondrocytes are linearly arranged in the EGP of lean mice but not in ob/ob mice [71]. Tibias were significantly shorter in ob/ob mice than in lean controls; the mean EGP height was reduced, and cell columns were fewer, shorter, and less organized, particularly the hypertrophying cells in the distal portion of the EGP. These differences may be attributed to the inhibitory effects of leptin deficiency on chondrocyte metabolism. Interestingly, the disturbed 2D columnar structure, with inhibited proliferation and extracellular matrix synthesis, was reversed in animals treated with leptin [71].

The role of leptin in regulating linear growth by affecting the EGP has been studied extensively [72, 73]. We have shown that leptin significantly increases tibial length in normal mice compared to pair-fed controls, probably acting through the parathyroid hormone-related protein/ Indian hedgehog loop [74]. The leptin receptor is expressed by EGP chondrocytes; adding leptin to ATDC5 cells increases their differentiation, as evident by increased expression of type X collagen $[29,75,76]$. Leptin directly stimulates EGP cartilage proliferation and differentiation [76-78] through its active, long-form, receptor $[29,77]$. Leptin administration was also shown to enhance levels of collagen type II, chondroitin-6-sulfate, and proteoglycans. This reflects the extent of leptin's effect on differentiation. Leptin strongly enhanced chondrocyte anabolic functions and induced synthesis of IGF1 and transforming growth factor b- 1 in the cartilage, at both the mRNA and the protein levels.

Few prospective cohort studies have addressed the relation of BMI with growth, from infancy to adolescence. Findings from population-based studies $[79,80]$ showed associations between higher BMI during early life and subsequent increases in length and height velocities. Consequent to faster linear growth, prepubescent children with obesity typically present with taller stature than their peers with normal weight [25]. Thus, we speculate that factors known to influence linear growth and previously shown to be positively correlated with BMI, such as IGF-1 [81], insulin, and leptin, may play important roles in the relation between higher BMI in early life and accelerated subsequent linear growth. Higher prepubertal BMI is also associated with insulin-induced reduction of sex hormonebinding globulin and increased sex steroid bioavailability, with marked influence on the GH-IGF-1 axis [82].

\section{Growth and Differentiation Factor-5}

An additional link between adipose tissue and longitudinal growth was identified in an in vitro model of 3T3L1 cells, induced to differentiate in culture into adipocytes and metatarsal bone rudiments [12]. The 3T3L1 
preadipocyte cell line was originally isolated for its ability to undergo differentiation into adipocytes in vitro [83]. We showed that the conditioned medium of 3T3L1 adipocytes stimulates growth of metatarsal rudiment bones in culture; the principal mediator in this setting was identified as GDF-5, secreted by adipocytes [12, 84]. Histological examination showed significant increases in the length of the bones exposed to GDF-5, in hypertrophic cell number and height and in the overall length of the hypertrophic zone. The GDF subfamily of bone morphogenetic factors (BMP) plays a central role in cartilage formation and in regulating cell differentiation and proliferation [85]. GDF-5 is active during mesenchymal cell condensation and in initiating early stages of chondrogenesis by promoting cell adhesion [86] and can increase the size of skeletal elements [86]. GDF-5 also stimulates proteoglycan production in chondrocyte-like cells, thus leading to increased aggrecan and type II collagen gene expression and increased production of proteoglycans [87]. GDF-5 binds specifically to bone morphogenetic protein receptor type-1B (BMPR1B), BMPR2, and actinrelated protein 2a (ACTR2a), forming a heterodimeric complex [88]. We have shown that BMPR1B is present in the metatarsal bones, specifically in the hypertrophic zone, coinciding with its site of action [12].

\section{High-Fat Diet}

Two rodent studies examined effects of HFD-induced obesity on linear growth. The first, performed in young male C57BL/6J mice, showed that HFD-induced obesity led to decreased trabecular bone density and slower cortical bone formation than standard chow. Serum leptin levels were correlated with trabecular but not cortical bone density. However, mean bone length did not differ between the 2 groups [89]. In contrast, in female C57BL/6J mice fed with a HFD, the obese mice had longer femurs in the early stages of the study, with no significant effect at age 20 weeks [90].

Another study investigated the effect of fast-food meals supplemented with caloric soft drink on linear growth in young fast-growing female rats. Two control groups enabled studying effects of the 2 main ingredients in fast-food diets: high levels of fat (corn oil) and sucrose ( $10 \%$ in drinking water). Only the fast-food meal led to damaged EGPs, shorter bones, and reduced bone strength. These harmful effects occurred initially through disruption of the normal endochondral ossification process in the EGP, leading to impaired growth and bone quality.
However, the deleterious effect on linear growth seems not to have been due to obesity nor to the high caloric intake/HFD but rather to the absence of the necessary nutritional elements critically required for normal development [91].

\section{Obesity and Linear Growth during Puberty}

Longitudinal studies [92] have reported inverse associations between high BMI for age in childhood and linear growth during adolescence. Furthermore, evidence suggests a relation between childhood obesity and the timing of pubertal milestones $[93,94]$; the latter is known to influence adolescent linear growth. A large Swedish study [92] showed that puberty started earlier, and the height gain during puberty was reduced in children with obesity. This was despite an association of increased BMI during ages $2-8$ years, with a parallel gain in height. Observational studies $[25,80]$ showed earlier pubertal development and slower linear growth among children with higher BMI during adolescence and a lesser growth spurt during puberty.

Increased adipose tissue can also release sex steroids that are involved in linear growth. Estrogen plays an important role in EGP maturation and fusion. EGP fusion is associated with senescence, which is manifested by a decline in the proliferative capacity of the resting chondrocytes with age [95] and which culminates in growth cessation. Changes in estrogen level are associated with tibial chondrocyte proliferation rate, EGP height, the number of proliferative chondrocytes, the number and size of hypertrophic chondrocytes, and column density $[96,97]$. We previously reported that aromatase is expressed in chondrocytes of the EGP, and that applying the aromatase inhibitor, letrozole, to young male mice led to significantly increased body weight and tail and tibial lengths, together with a marked increase in EGP height [98]. In a subsequent study, we described crosstalk between leptin and aromatase in chondrocytes. Administration of leptin augmented aromatase mRNA expression and protein content and augmented leptin and estrogen receptor gene expression. The increased aromatase expression enhanced aromatization (conversion of testosterone to estrogen). The increased locally produced estrogen then bound to its receptors (also increased), enhancing the senescent decline in the EGP chondrocyte proliferation rate and reducing EGP height [99]. These results were also supported by a study that showed a significantly higher longitudinal growth rate in animals treated with leptin $+(\mathrm{ER})-\alpha$ inhibitor than only with leptin. This indicates that the concurrent increase in es- 
trogen levels during leptin treatment antagonizes the growth-promoting actions of leptin [100].

Rapid weight gain in early childhood is often accompanied by bone age advancement [101]; this reduces the height attained in late adolescence and impairs the potential genetic adult height $[102,103]$. Therefore, the increased insulin secretion that normally occurs in adolescence is probably involved in activating IRs at the EGP. Hyperinsulinemia was found to be a strong predictor of advanced bone age in children with obesity [104]. Since leptin also has a direct effect on skeletal growth centers, its increased levels in adolescents with obesity may also contribute to accelerated bone maturation, with earlier epiphyseal closure and impaired genetic growth potential. Accelerated EGP maturation in children may also result, due to an early effect of estrogen on the EGP. Another pathway is the increased aromatization in adipose tissue, of androgens into estrogens, which may accelerate growth but also cause accelerated epiphyseal fusion in children with obesity [96].

\section{Linear Growth in Monogenetic Obesity and}

\section{Syndromic Obesity}

Several genes, such as proopiomelanocortin, leptin receptor $(L E P R)$, leptin $(L E P)$, proconvertase 1 prohormone convertase 1 , and melanocortin 4 receptor $(M C 4 R)$, have been confirmed as harboring mutations that are causal to the onset of monogenic obesity with very early onset of weight gain. These genes are involved in the leptin/melanocortin axis, which has an essential role in human energy homeostasis and endocrine function. Homozygous mutations in the LEP and LEPR genes cause hyperphagia and severe early-onset obesity from the first year of life. This is associated with pubertal delay due to hypogonadotropic hypogonadism. These patients also have hyperinsulinemia and insulin resistance. Gibson et al. [105] reported normal stature in their patient with $L E P$ deficiency.

Farooqi et al. [106] reported normal linear growth in children with LEPR mutations and similar standard deviation scores for height to those of children with the same degree of obesity and without LEPR mutations. Serum levels of IGF-1 were age appropriate, and GH was secreted in a pulsatile fashion. However, the final height was reduced in adults with $L E P R$ mutations, probably due to the lack of a pubertal growth spurt.

Mutations in the MC4R are the most common mutations in children with monogenic early-onset obesity. Lubrano-Berthelier et al. [107] reported accelerated growth in children with the $M C 4 R^{-1-}$; this feature was also found in individuals with heterozygous MC4R mutations. This result suggests that in humans, the positive effects of leptin on linear growth may not be mediated through the melanocortin pathway.

Height standard deviation score was found to be significantly greater in children who were MC4R deficient compared with controls, at age 5 years and continuing throughout childhood. Fasting IGF-I, IGF-II, acid-labile subunit, and IGFBP-3 concentrations were similar in the 2 groups. GH levels were markedly suppressed in children in the control group who were with obesity, but pulsatile GH secretion was retained in MC4R deficiency [108]. In individuals with MC4R deficiency, increased linear growth in childhood leads to a greater adult final height, which exceeds that predicted by obesity alone. GH pulsatility is maintained in MC4R deficiency and suggests a role for MC4R in controlling hypothalamic somatostatinergic tone. Fasting insulin levels are significantly higher in children with MC4R mutations [109]. Both these factors may contribute to the accelerated growth phenotype characteristic of MC4R deficiency.

In contrast to monogenic disorders, obesity in syndromic conditions typically develops after infancy. Examples include Prader-Willi syndrome (PWS), BardetBiedl syndrome (BBS), Alström syndrome, and Albright's hereditary osteodystrophy syndrome. These syndromes are often associated with impaired growth.

In PWS, following a period of limited catch-up weight gain at age 6-18 months, children develop an insatiable appetite, resulting in obesity by age 6 years. In children with PWS compared to healthy children with obesity, the following parameters are significantly higher: ghrelin levels, total adiponectin, high molecular weight (HMW) adiponectin, and the HMW adiponectin:leptin ratio; fasting insulin levels are lower $[110,111]$. The relatively high levels of ghrelin in these children may contribute to hyperphagia and excess weight gain [112]. Affected children often also have poor linear growth, with short stature and delayed puberty [113]. GH deficiency in the context of PWS has been documented in many studies. The GH deficiency is independent of obesity and manifests in low spontaneous and pharmacologically stimulated GH secretion and low serum concentrations of IGF-I $[114,115]$. This contrasts with overnutrition in common obesity, which is associated with normal or increased IGF-I levels.

In BBS, energy dysregulation is thought to arise from a greater degree of leptin resistance than presents in individuals with obesity who do not have BBS [116]. A study of 50 individuals with BBS [117] showed shorter height than individuals with obesity in a control group. However, the height of the BBS group approximated the pop- 
Fig. 2. Regulatory hormones affecting the process of puberty in the constellation of obesity. FSH, follicle-stimulating hormone; GnRH, gonadotropin-releasing hormone; kiss1, kisspeptin-1; LH, luteinizing hormone; mTOR, mammalian target of rapamycin; SHBG, sex hormone-binding globulin.

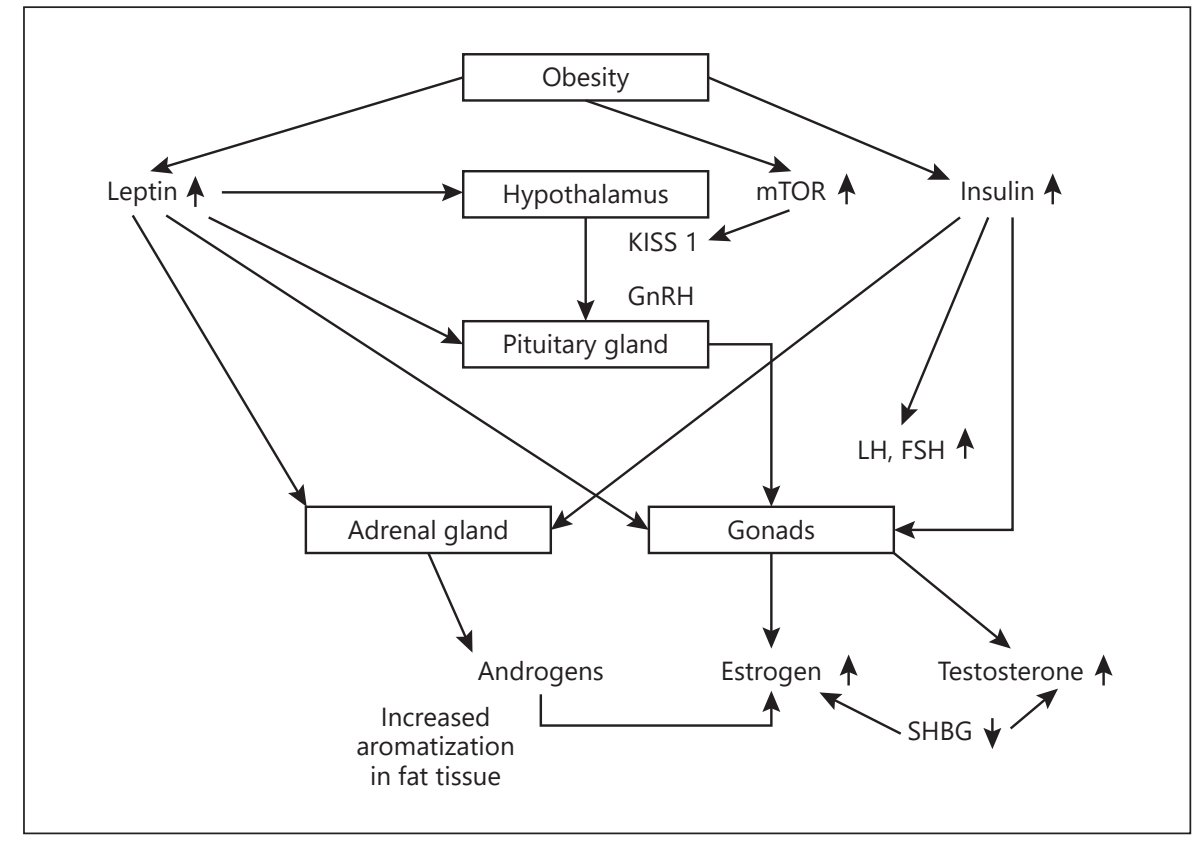

ulation mean for age and sex. This indicates that they were not abnormally short, but rather lacked the bone age advancement and accelerated growth typically seen in healthy individuals with obesity.

\section{Obesity and Puberty}

Multiple factors affect pubertal development, including genetic and environmental conditions. The genes that are involved controlgonadotropin-releasinghormone $(\mathrm{GnRH})$ hypothalamic secretion, pituitary development, hormone synthesis and bioactivity, energy homeostasis and growth, and potential peripheral feedback from sex steroids [118]. Adequate nutrition is a key permissive factor for the normal timing and tempo of pubertal development.

The strong relation between childhood BMI and the earlier timing of puberty supports the critical mass theory of sexual maturation [119]. Obesity may alter secretion and sensitivity of hormones, including leptin and insulin. Leptin levels rise gradually with age, prior to puberty in adolescents, thus suggesting that a threshold effect may trigger puberty $[13,120]$.

Adipose tissue is a source of a large number of secreted signals and is a site for the conversion of cortisone to active cortisol [121] and of androgens to estrogen [122]. Accumulated adipose tissue may therefore contribute to the orchestrated controls for pubertal development, as presented in Figure 2. The main functions of hormones/ adipokine mediators in puberty are presented below and summarized in Table 1.

\section{Kisspeptin}

Hypothalamic neurons that produce kisspeptins, encoded by Kiss1, have been shown to play a master role in the neuroendocrine pathways controlling puberty. The Kiss1 system is highly sensitive to changes in metabolic and nutritional cues, as well as to alterations in leptin levels and signaling. This suggests an effect of body energy reserves and leptin levels on the reproductive axis, via modulation of Kiss1 neurons [123].

Excess adiposity appears to have a biphasic impact on the Kiss1 system. Overfeeding during the postnatal/peripubertal period increases hypothalamic Kiss1 expression and advances puberty onset. However, in rodents, an association was shown of persistent energy excess and obesity in adulthood with suppression of Kiss 1 expression and reproductive dysfunction [124].

Key cellular metabolic sensors, including the mammalian target of rapamycin, AMP-activated protein kinase, and the fuel-sensing deacetylase, sirtuin (SIRT)-1, have also been shown to be involved in the metabolic modulation of puberty. AMP-activated protein kinase and SIRT1 operate as major molecular effectors for metabolic control of Kiss1 neurons and, thereby, puberty onset. The central mechanisms whereby early-onset obesity with elevated circulating leptin levels may advance pubertal maturation are likely to involve changes in SIRT1 activity in Kiss1 neurons. Thus, premature removal of SIRT1 from the Kiss1 promoter would contribute to an earlier 
change in the epigenetic landscape of this promoter toward a more permissive configuration. This would increase Kiss1 expression with earlier activation of GnRH neurosecretion and, thereby, puberty onset [125].

\section{Leptin}

Several explanations are plausible for the association of obesity with earlier puberty [13]. The higher leptin levels in children with obesity than lean children may contribute to their earlier onset of puberty. In the hypothalamus, leptin can stimulate the secretion of kisspeptin and subsequently activate the hypothalamic-pituitary-gonadal (HPG) axis and accelerate GnRH secretion in the arcuate hypothalamic neurons in a dose-dependent manner, thereby hastening puberty [126].

The relation between leptin and gonadotropins has been reported to be sex specific. In girls entering puberty, a peak in leptin concentrations preceded peaks in luteinizing hormone (LH) and follicular-stimulating hormone concentrations [127]. Leptin concentrations increase before the onset of puberty in boys, but the concentrations fall in midpuberty, in contrast to girls [128]. This refutes a direct relation between leptin and puberty in boys. The sex difference in leptin concentrations in puberty may explain the later puberty onset in boys with obesity and the earlier puberty onset in girls with obesity. An important sexual dimorphism has also been shown of the interaction of kisspeptin with GnRH secretion [129].

Leptin receptors have been identified in the hypothalamus and in the gonadotroph cells of the anterior pituitary [130]. In the anterior pituitary, leptin directly stimulates release of LH and, to a lesser extent, follicular-stimulating hormone, via activation by nitric oxide synthase in the gonadotrophs [131]. Effects of leptin on the gonads are implied by expression of functional leptin receptors on the surface of ovarian follicular cells, including granulose, theca, and interstitial cells [132], as well as Leydig cells [133].

NPY, a potent stimulator of food intake, has an inhibitory effect on GnRH secretion [134]. NPY expression in the arcuate nucleus is decreased by leptin administration, which disrupts its inhibitory action on pulsatile GnRH release [135].

At high physiological doses, leptin appears to antagonize the augmenting effect of growth factors (IGF-1) and hormones (insulin and glucocorticoids) on gonadotropinstimulated steroidogenesis in follicular and theca ovarian cells throughout the menstrual cycle [136]. In Leydig cells, leptin exerts inhibitory effects on testosterone production
[133]. Hence, leptin possesses a bimodal action on the HPG axis, depending on its serum levels. Specifically, low leptin levels result in HPG axis dysfunction, and leptin administration in low doses may have a permissive, threshold effect on the central networks that regulate gonadotropin secretion. On the other hand, high serum leptin levels in people with obesity may have an inhibitory effect on the gonads.

Adrenarche generally begins parallel to the preadolescent rise in BMI, the gradual increase in plasma insulin, and the increase in IGF-1 serum levels [137]. Specific, dose-dependent, stimulatory activity of leptin on enzymes has been shown as essential for the synthesis of adrenal androgens [138]. Furthermore, adrenal androgen levels are increased in children with obesity [139] and may therefore also be responsible for their accelerated growth before puberty.

\section{Adiponectin}

Individuals with obesity often develop a chronic lowgrade inflammatory state, indicated by a high level of circulating inflammatory cytokines (TNF- $\alpha$ and IL-6). TNF- $\alpha$ and IL- 6 inhibit the expression of adiponectin, and indeed individuals with obesity often have low levels of adiponectin.

Adiponectin can affect the HPG axis due to the expression of adiponectin receptors in the hypothalamus, pituitary gland, and gonads [140]. Adiponectin regulates puberty onset, as it inhibits secretion of kisspeptin and $\mathrm{GnRH}$ in the hypothalamus and the release of $\mathrm{GH}$ and $\mathrm{LH}$ in the pituitary gland, thereby inhibiting puberty onset [141]. Total adiponectin was found to be significantly lower and HMW adiponectin higher in girls with than without central precocious puberty [142]. Total adiponectin correlated negatively with the progression of puberty in girls. Therefore, a low level of total adiponectin or high levels of inflammatory cytokines in individuals with obesity can promote the onset of puberty.

\section{Insulin}

Insulin has been shown to be involved in the modulation of GnRH neurons and reproductive development [143]. An in vivo experimental model demonstrated that increasing insulin concentrations stimulated LH secretion, while an in vitro model showed direct dose-dependent stimulation of $\mathrm{GnRH}$ secretion by insulin [144]. This suggests that greater insulin resistance/hyperinsulinemia 
associated with obesity may lead to premature pubertal onset. Hyperinsulinemia may also increase LH-stimulated ovarian and adrenal steroidogenesis and its association with precocious adrenarche [145].

Peripubertal obesity with insulin resistance and compensatory hyperinsulinemia augments ovarian/adrenal androgen production and also leads to decreased sex hormone-binding globulin. This leads to increased androgen bioavailability and bioavailability of sex steroids including estradiol [146]. In addition, aromatase action of adipose tissue increases androgen conversion to estrogens. Aromatase activity within the adipocyte is dependent on fat mass. Thus, obesity may result in greater peripheral conversion of androstenedione to estrone and testosterone to estradiol, independent of gonadotropins.

\section{Adrenal Androgens}

Prepubertal children with obesity have increased adrenal androgens [147]. Therefore, presumably, marked weight gain and obesity (associated with high insulin levels) are involved in premature adrenarche [148]. Girls with premature adrenarche were shown to have higher BMI and elevated levels of plasma leptin, cortisol, androgens, estradiol, and estrone compared to age-matched girls without adrenarche [149]. This indicates that girls with premature adrenarche are characterized by features of increased adiposity and hypothalamic-pituitary-adrenal axis activity.

Increased androgen levels can, in turn, promote pubertal development, acting peripherally or centrally on the HPG axis. In prepubertal girls, increased androgen concentrations have been suggested to facilitate pubertal increase in $\mathrm{GnRH}$ secretion, possibly leading to early pubertal onset [150].

Potential mechanisms of obesity-associated hyperandrogenemia include insulin resistance, enhanced androgen production in an expanded fat mass, and potential effects of abnormal adipokine/cytokine levels. Kinyua et al. [151] suggested that insulin upregulates steroidogenic factor-1 (transcriptional factor) and the steroidogenic genes directly, independent of the CRH-ACTH-MC2RPKA pathway. This increases the generation of adrenal gland hormones.

Adipose tissue contains several steroidogenic enzymes. A number of studies have demonstrated significant steroid hormone uptake and conversion by adipose tissues. Activities and mRNAs of aromatase, 3beta-hydroxysteroid dehydrogenase (HSD), 3alpha-HSD, 11beta-HSD, 17beta-HSD, 7alpha-hydroxylase, 17alpha-hy- droxylase, and 5alpha-reductase have been detected in adipose tissue [152].

Insulin resistance in childhood obesity is characterized by higher $5 \alpha$-reductase and lower 11ßHSD1 [153]. The enzyme $5 \alpha$-reductase converts testosterone to the highly potent androgen dihydrotestosterone. Thus, increased $5 \alpha$-reductase activity related to an expanded fat mass represents another mechanism by which obesity may promote hyperandrogenism. An additional hypothesis holds that altered peripheral cortisol metabolism related to obesity leads to a compensatory increase of ACTH drive. This contributes to increased adrenal androgen production. Specifically, reduced cortisol negative feedback on ACTH secretion could be related to (1) augmented cortisol inactivation by increased $5 \alpha$-reductase activity and (2) decreased activity of $11 \beta$-hydroxysteroid dehydrogenase type 1 (11HSD1), which converts cortisone to cortisol. Recently, Gawlik et al. [154] reported that children with obesity and insulin resistance were characterized by high adrenal androgens, glucocorticoids, and mineralocorticoid metabolites; higher $5 \alpha$-reductase and 21-hydroxylase activity; and lower $11 \beta \mathrm{HSD} 1$ activity.

\section{Obesity and Pubertal Onset and Advancement}

The onset and timing of puberty in humans are dependent on numerous factors, including genetic variability, energy balance, multiple neuroendocrine pathways, and hormonal profiles. Moreover, successful reproduction is acknowledged as requiring suitable energy stores to support the associated physiological functions [155]. Therefore, puberty is "metabolically gated" to prevent fertility in conditions of energy insufficiency, such that metabolic conditions and energy reserves play important roles in modulating puberty timing [155].

In the last centuries, pubertal timing has changed dramatically. An association has been shown between obesity and earlier puberty onset among adolescent girls $[156,157]$. Data of American girls observed the onset of thelarche at younger ages than previously documented, with important differences according to ethnicity and BMI, thus confirming and extending patterns seen previously [158]. Nonetheless, the tempo from breast development to menarche appears to have lengthened. Furthermore, girls with overweight and obesity are more likely to experience menarche at younger ages [159].

In contrast to these well-documented findings in girls, less is known of secular trends in pubertal maturation in boys and possible relations to obesity. An inverse linear relation has been reported between BMI and male pubertal onset $[160,161]$. However, others reported delayed 
onset in boys with obesity compared to boys with overweight, thus indicating a nonlinear, J-shaped association [162]. However, according to recent data, the previously held notion that boys with obesity might progress to puberty at a slower pace than their peers without obesity is no longer substantiated $[161,163,164]$.

Impaired fertility markers, reduced reproductive functions with low sperm counts, and reduced sperm function have been observed in males with obesity [165]. Adipocytokines and inflammatory cytokines have all been shown to impact reproductive function [166].

\section{Environmental Factors and Associations with Puberty}

Both pubertal timing and obesity are influenced by the environment, and the interaction between genes and environments is strong during critical periods of development such as puberty. This interaction is due to substances such as dietary factors and endocrine-disrupting chemicals (EDCs) that derail the normal hormonal process. Potential dietary factors include total caloric intake, fat intake, protein intake, and fiber intake. Several studies have suggested that earlier onset of breast development may occur independent of HPG axis activation, perhaps through EDCs acting on adipocytes or on other hormonally responsive tissues [167].

Several epidemiological studies $[168,169]$ have reported an association of high total energy intake, as well as a high animal (red meat) versus vegetable protein ratio, with early menarche. Total dietary fat consumption may lead to earlier menarche, although the literature is inconsistent [169]. Dietary protein was associated with earlier onsets of the pubertal growth spurt, the age at peak height velocity, and the age at menarche/voice break [170]. EDCs can also act as obesogens and promote early adiposity rebound, changing metabolic or peripheral signals and increasing adrenal androgen levels, thus inducing early pubertal development [171]. An example of such an EDC is bis (2-ethylhexyl) phthalate (DEHP), a plasticizer that is noncovalently bound to plastics and easily released. Children are particularly vulnerable and susceptible to DEHP effects due to higher exposure levels and developmental processes. A juvenile toxicity study was performed to characterize the DEHP hazard and mode of action in rats of both sexes during the peripubertal period - corresponding to the childhood phase - from weaning, postnatal day 23, to full sexual maturity (postnatal day 60). DEHP was administered by gavage for 28 days.
The main targets of DEHP during the juvenile period were the liver and metabolic system in both sexes, while sex-specific effects were recorded in the reproductive system (male rats) and the thyroid (female rats). Thus, DEHP exposure during the peripubertal period at dose levels derived from a biomonitoring study in children can induce sex-specific imbalances [172]. Recent studies in humans and animals have shown that metabolic pathways involved in regulating growth, body weight gain, and sexual maturation are largely affected by epigenetic programming that can impact both current and future generations.

\section{Conclusions}

The escalating prevalence of obesity is currently observed among children and adolescents in the majority of countries. In addition to other obesity-related comorbidities, children and adolescents with obesity are subject to accelerated linear growth and the risk of impairment of their potential genetic adult height and early puberty, with its psychological consequences. These findings may prove helpful to clinicians in their efforts to raise motivation among young people with obesity to comply with lifestyle modifications.

\section{Acknowledgement}

The authors wish to thank Cindy Cohen for the editorial assistance.

\section{Conflict of Interest Statement}

Shlomit Shalitin is an Associate Editor of Hormone Research in Pediatrics. The authors have no other conflicts of interest relevant to this article to disclose.

\section{Funding Sources}

The authors did not receive any funding.

\section{Author Contributions}

S.S. and G.G.Y. were responsible for drafting the article and revising it critically for important intellectual content. Both authors read and approved the final manuscript. 


\section{References}

1 NCD Risk Factor Collaboration (NCD-RisC). Worldwide trends in body-mass index, underweight, overweight, and obesity from 1975 to 2016: a pooled analysis of 2416 populationbased measurement studies in 128.9 million children, adolescents, and adults. Lancet. 2017;390(10113):2627-42.

2 Kumar S, Kelly AS. Review of childhood obesity: from epidemiology, etiology, and comorbidities to clinical assessment and treatment. Mayo Clin Proc. 2017;92(2):251-65.

3 Ogden CL, Carroll MD, Kit BK, Flegal KM. Prevalence of childhood and adult obesity in the United States, 2011-2012. JAMA. 2014; 311(8):806-14.

4 Bleich SN, Ku R, Wang YC. Relative contribution of energy intake and energy expenditure to childhood obesity: a review of the literature and directions for future research. Int J Obes (Lond). 2011;35(1):1-15.

5 Sisson SB, Church TS, Martin CK, TudorLocke C, Smith SR, Bouchard C, et al. Profiles of sedentary behavior in children and adolescents: the US National Health and Nutrition Examination Survey, 2001-2006. Int J Pediatr Obes. 2009;4(4):353-9.

6 Berardis S, Sokal E. Pediatric non-alcoholic fatty liver disease: an increasing public health issue. Eur J Pediatr. 2014;173(2):131-9.

7 Friedemann C, Heneghan C, Mahtani K, Thompson M, Perera R, Ward AM. Cardiovascular disease risk in healthy children and its association with body mass index: systematic review and meta-analysis. BMJ. 2012;345: e4759.

8 Pulgaron ER, Delamater AM. Obesity and type 2 diabetes in children: epidemiology and treatment. Curr Diab Rep. 2014;14(8):508.

9 Park MH, Falconer C, Viner RM, Kinra S. The impact of childhood obesity on morbidity and mortality in adulthood: a systematic review. Obes Rev. 2012;13(11):985-1000.

10 Li W, Liu Q, Deng X, Chen Y, Liu S, Story M. Association between obesity and puberty timing: a systematic review and meta-analysis. Int J Environ Res Public Health. 2017;14(10).

11 Havel PJ. Control of energy homeostasis and insulin action by adipocyte hormones: leptin, acylation stimulating protein, and adiponectin. Curr Opin Lipidol. 2002;13(1):51-9.

12 Shtaif B, Dror N, Bar-Maisels M, Phillip M, Gat-Yablonski G. Growth without growth hormone: can growth and differentiation factor 5 be the mediator?. Growth Factors. 2015; 33(4):309-18.

13 Shalitin S, Phillip M. Role of obesity and leptin in the pubertal process and pubertal growth-a review. Int J Obes Relat Metab Disord. 2003;27(8):869-74.

14 Drake AJ, Reynolds RM. Impact of maternal obesity on offspring obesity and cardiometabolic disease risk. Reproduction. 2010;140(3): 387-98.

15 Challier JC, Basu S, Bintein T, Minium J, Hotmire K, Catalano PM, et al. Obesity in preg- nancy stimulates macrophage accumulation and inflammation in the placenta. Placenta. 2008;29(3):274-81.

16 Zhang C, Hediger ML, Albert PS, Grewal J, Sciscione A, Grobman WA, et al. Association of maternal obesity with longitudinal ultrasonographic measures of fetal growth: findings from the NICHD fetal growth studies-singletons. JAMA Pediatr. 2018;172(1):24-31.

17 Sewell MF, Huston-Presley L, Super DM, Catalano P. Increased neonatal fat mass, not lean body mass, is associated with maternal obesity. Am J Obstet Gynecol. 2006;195(4):11003

18 Zeyda M, Stulnig TM. Obesity, inflammation, and insulin resistance-a mini-review. Gerontology. 2009;55(4):379-86.

19 Ramsay JE, Ferrell WR, Crawford L, Wallace AM, Greer IA, Sattar N. Maternal obesity is associated with dysregulation of metabolic, vascular, and inflammatory pathways. J Clin Endocrinol Metab. 2002;87(9):4231-7.

20 Denison FC, Roberts KA, Barr SM, Norman JE. Obesity, pregnancy, inflammation, and vascular function. Reproduction. 2010; 140(3):373-85.

21 Schaab M, Kratzsch J. The soluble leptin receptor. Best Pract Res Clin Endocrinol Metab. 2015;29(5):661-70.

22 Misra VK, Straughen JK, Trudeau S. Maternal serum leptin during pregnancy and infant birth weight: the influence of maternal overweight and obesity. Obesity (Silver Spring). 2013;21(5):1064-9.

23 Hauguel-de Mouzon S, Catalano P. Adiponectin: are measurements clinically useful in pregnancy? Diabetes Care. 2013;36(6):14346.

24 Hinkle SN, Rawal S, Liu D, Chen J, Tsai MY, Zhang C. Maternal adipokines longitudinally measured across pregnancy and their associations with neonatal size, length, and adiposity. Int J Obes (Lond). 2019;43(7):1422-34.

25 Stovitz SD, Demerath EW, Hannan PJ, Lytle LA, Himes JH. Growing into obesity: patterns of height growth in those who become normal weight, overweight, or obese as young adults. Am J Hum Biol. 2011;23(5):635-41.

26 Baron J, Savendahl L, De Luca F, Dauber A, Phillip M, Wit JM, et al . Short and tall stature: a new paradigm emerges. Nat Rev Endocrinol. 2015;11(12):735-46.

27 Gat-Yablonski G, De Luca F. Effect of Nutrition on Statural Growth. Horm Res Paediatr. 2017;88(1):46-62.

28 Wu S, Aguilar AL, Ostrow V, De Luca F. Insulin resistance secondary to a high-fat diet stimulates longitudinal bone growth and growth plate chondrogenesis in mice. Endocrinology. 2011;152(2):468-75.

29 Ben-Eliezer M, Phillip M, Gat-Yablonski G. Leptin regulates chondrogenic differentiation in ATDC5 cell-line through JAK/STAT and MAPK pathways. Endocrine. 2007;32(2): 235-44.
30 Scherer PE, Williams S, Fogliano M, Baldini G, Lodish HF. A novel serum protein similar to $\mathrm{C} 1 \mathrm{q}$, produced exclusively in adipocytes. J Biol Chem. 1995;270(45):26746-9.

31 Klein KO, Larmore KA, de Lancey E, Brown JM, Considine RV, Hassink SG. Effect of obesity on estradiol level, and its relationship to leptin, bone maturation, and bone mineral density in children. J Clin Endocrinol Metab. 1998;83(10):3469-75.

32 Kreitschmann-Andermahr I, Suarez P, Jennings R, Evers N, Brabant G. GH/IGF-I regulation in obesity-mechanisms and practical consequences in children and adults. Horm Res Paediatr. 2010;73(3):153-60.

33 Iranmanesh A, Lizarralde G, Veldhuis JD. Age and relative adiposity are specific negative determinants of the frequency and amplitude of growth hormone $(\mathrm{GH})$ secretory bursts and the half-life of endogenous GH in healthy men. J Clin Endocrinol Metab. 1991; 73(5):1081-8.

34 Lichanska AM, Waters MJ. New insights into growth hormone receptor function and clinical implications. Horm Res. 2008;69(3):13845.

35 Ballerini MG, Ropelato MG, Domene HM, Pennisi P, Heinrich JJ, Jasper HG. Differential impact of simple childhood obesity on the components of the growth hormone-insulinlike growth factor (IGF)-IGF binding proteins axis. J Pediatr Endocrinol Metab. 2004; 17(5):749-57.

$36 \mathrm{Qu}$ XD, Gaw Gonzalo IT, Al Sayed MY, Cohan $\mathrm{P}$, Christenson PD, Swerdloff RS, et al. Influence of body mass index and gender on growth hormone $(\mathrm{GH})$ responses to GH-releasing hormone plus arginine and insulin tolerance tests. J Clin Endocrinol Metab. 2005;90(3):1563-9.

37 Rasmussen MH, Hvidberg A, Juul A, Main KM, Gotfredsen A, Skakkebaek NE, et al. Massive weight loss restores 24-hour growth hormone release profiles and serum insulinlike growth factor-I levels in obese subjects. J Clin Endocrinol Metab. 1995;80(4):140715.

38 Iniguez G, Gonzalez CA, Argandona F, Kakarieka E, Johnson MC, Cassorla F. Expression and protein content of IGF-I and IGF-I receptor in placentas from small, adequate and large for gestational age newborns. Horm Res Paediatr. 2010;73(5):320-7.

39 Bouhours-Nouet N, Gatelais F, Boux de Casson F, Rouleau S, Coutant R. The insulin-like growth factor-I response to growth hormone is increased in prepubertal children with obesity and tall stature. J Clin Endocrinol Metab. 2007;92(2):629-35

40 Rogers I, Metcalfe C, Gunnell D, Emmett P, Dunger D, Holly J, et al. Insulin-like growth factor-I and growth in height, leg length, and trunk length between ages 5 and 10 years. J Clin Endocrinol Metab. 2006;91(7): 2514-9. 
41 Date Y, Nakazato M, Hashiguchi S, Dezaki K, Mondal MS, Hosoda H, et al. Ghrelin is present in pancreatic alpha-cells of humans and rats and stimulates insulin secretion. Diabetes. 2002;51(1):124-9.

42 Tschop M, Weyer C, Tataranni PA, Devanarayan V, Ravussin E, Heiman ML. Circulating ghrelin levels are decreased in human obesity. Diabetes. 2001;50(4):707-9.

43 Bacha F, Arslanian SA. Ghrelin suppression in overweight children: a manifestation of insulin resistance?. J Clin Endocrinol Metab. 2005;90(5):2725-30.

44 Recinella L, Shohreh R, Salvatori R, Orlando G, Vacca M, Brunetti L. Effects of isolated GH deficiency on adipose tissue, feeding and adipokines in mice. Growth Horm IGF Res. 2013 Dec;23(6):237-42.

45 Recinella L, Leone S, Ferrante C, Chiavaroli A Shohreh R, Di Nisio C, et al. Effects of growth hormone-releasing hormone gene targeted ablation on ghrelin-induced feeding. Growth Horm IGF Res. 2017 Dec;37:40-6.

46 Savastano S, Di Somma C, Barrea L, Colao A. The complex relationship between obesity and the somatropic axis: the long and winding road. Growth Horm IGF Res. 2014;24(6): 221-6.

47 Cornford AS, Barkan AL, Horowitz JF. Rapid suppression of growth hormone concentration by overeating: potential mediation by hyperinsulinemia. J Clin Endocrinol Metab. 2011;96(3):824-30.

48 Luque RM, Kineman RD. Impact of obesity on the growth hormone axis: evidence for a direct inhibitory effect of hyperinsulinemia on pituitary function. Endocrinology. 2006; 147(6):2754-63.

49 Maccario M, Grottoli S, Procopio M, Oleandri SE, Rossetto R, Gauna C, et al. The GH/ IGF-I axis in obesity: influence of neuro-endocrine and metabolic factors. Int $J$ Obes Relat Metab Disord. 2000;24(Suppl 2):S96-

50 Bucher H, Zapf J, Torresani T, Prader A, Froesch ER, Illig R. Insulin-like growth factors I and II, prolactin, and insulin in 19 growth hormone-deficient children with excessive, normal, or decreased longitudinal growth after operation for craniopharyngioma. N Engl J Med. 1983;309(19):1142-6.

51 Bistritzer T, Chalew SA, Lovchik JC, Kowarski AA. Growth without growth hormone: the "invisible" GH syndrome. Lancet. 1988; 1(8581):321-3.

52 Attia N, Tamborlane WV, Heptulla R, Maggs D, Grozman A, Sherwin RS, et al. The metabolic syndrome and insulin-like growth factor I regulation in adolescent obesity. J Clin Endocrinol Metab. 1998;83(5):1467-71.

53 Siddle K. Molecular basis of signaling specificity of insulin and IGF receptors: neglected corners and recent advances. Front Endocrinol (Lausanne). 2012;3:34.

54 Geffner ME. The growth without growth hormone syndrome. Endocrinol Metab Clin North Am. 1996;25(3):649-63.
55 Heinze E, Vetter U, Voigt KH. Insulin stimulates skeletal growth in vivo and in vitrocomparison with growth hormone in rats. Diabetologia. 1989;32(3):198-202.

56 Maor G, Silbermann M, von der Mark K, Heingard D, Laron $\mathrm{Z}$. Insulin enhances the growth of cartilage in organ and tissue cultures of mouse neonatal mandibular condyle. Calcif Tissue Int. 1993;52(4):291-9.

57 Phornphutkul C, Wu KY, Gruppuso PA. The role of insulin in chondrogenesis. Mol Cell Endocrinol. 2006;249(1-2):107-15.

58 Johnson TR, Blossey BK, Denko CW, Ilan J. Expression of insulin-like growth factor I in cultured rat hepatocytes: effects of insulin and growth hormone. Mol Endocrinol. 1989;3(3): $580-7$.

59 Wu S, Zhang Y, De Luca F. The effect of a highcalorie diet on bone growth is mediated by the insulin receptor. Bone. 2019;122:166-75.

60 Soto N, Bazaes RA, Pena V, Salazar T, Avila $A$, Iniguez $G$, et al. Insulin sensitivity and secretion are related to catch-up growth in small-for-gestational-age infants at age 1 year: results from a prospective cohort. J Clin Endocrinol Metab. 2003;88(8):3645-50.

61 Lee NK, Karsenty G. Reciprocal regulation of bone and energy metabolism. Trends Endocrinol Metab. 2008;19(5):161-6.

62 Yang WS, Lee WJ, Funahashi T, Tanaka S, Matsuzawa Y, Chao CL, et al. Weight reduction increases plasma levels of an adipose-derived anti-inflammatory protein, adiponectin. J Clin Endocrinol Metab. 2001;86(8):3815-9.

63 Lago R, Gomez R, Otero M, Lago F, Gallego $\mathrm{R}$, Dieguez C, et al. A new player in cartilage homeostasis: adiponectin induces nitric oxide synthase type II and pro-inflammatory cytokines in chondrocytes. Osteoarthritis Cartilage. 2008;16(9):1101-9.

64 Challa TD, Rais Y, Ornan EM. Effect of adiponectin on ATDC5 proliferation, differentiation and signaling pathways. Mol Cell En docrinol. 2010;323(2):282-91.

65 Mitsui Y, Gotoh M, Fukushima N, Shirachi I, Otabe S, Yuan X, et al. Hyperadiponectinemia enhances bone formation in mice. BMC Musculoskelet Disord. 2011;12:18.

66 Hassink SG, Sheslow DV, de Lancey E, Opentanova I, Considine RV, Caro JF. Serum leptin in children with obesity: relationship to gender and development. Pediatrics. 1996;98(2 Pt 1):201-3.

67 Tannenbaum GS, Gurd W, Lapointe M. Leptin is a potent stimulator of spontaneous pulsatile growth hormone $(\mathrm{GH})$ secretion and the $\mathrm{GH}$ response to $\mathrm{GH}$-releasing hormone. Endocrinology. 1998;139(9):3871-5.

68 Hakansson ML, Brown H, Ghilardi N, Skoda RC, Meister B. Leptin receptor immunoreactivity in chemically defined target neurons of the hypothalamus. J Neurosci. 1998;18(1): 559-72.

69 Steppan CM, Crawford DT, Chidsey-Frink $\mathrm{KL}, \mathrm{Ke} \mathrm{H}$, Swick AG. Leptin is a potent stimulator of bone growth in ob/ob mice. Regul Pept. 2000;92(1-3):73-8.
70 Iwaniec UT, Boghossian S, Lapke PD, Turner RT, Kalra SP. Central leptin gene therapy corrects skeletal abnormalities in leptin-deficient ob/ob mice. Peptides. 2007;28(5):1012-9.

71 Hung J, Al-Nakkash L, Broderick TL, Castro M, Plochocki JH. Leptin-deficient mice have altered three-dimensional growth plate histomorphometry. Diabetol Metab Syndr. 2019;11:8.

72 Gat-Yablonski G, Phillip M. Leptin and regulation of linear growth. Curr Opin Clin Nutr Metab Care. 2008;11(3):303-8.

73 Turner RT, Kalra SP, Wong CP, Philbrick KA, Lindenmaier LB, Boghossian S, et al. Peripheral leptin regulates bone formation. J Bone Miner Res. 2013;28(1):22-34.

74 Gat-Yablonski G, Shtaif B, Phillip M. Leptin stimulates parathyroid hormone related peptide expression in the endochondral growth plate. J Pediatr Endocrinol Metab. 2007; 20(11):1215-22.

75 Kishida Y, Hirao M, Tamai N, Nampei A, Fujimoto $\mathrm{T}$, Nakase T, et al. Leptin regulates chondrocyte differentiation and matrix maturation during endochondral ossification. Bone. 2005;37(5):607-21.

76 Nakajima R, Inada H, Koike T, Yamano T. Effects of leptin to cultured growth plate chondrocytes. Horm Res. 2003;60(2):91-8.

77 Maor G, Rochwerger M, Segev Y, Phillip M. Leptin acts as a growth factor on the chondrocytes of skeletal growth centers. J Bone Miner Res. 2002;17(6):1034-43.

78 Gat-Yablonski G, Ben-Ari T, Shtaif B, Potievsky O, Moran O, Eshet R, et al. Leptin reverses the inhibitory effect of caloric restriction on longitudinal growth. Endocrinology. 2004;145(1):343-50.

$79 \mathrm{He}$ Q, Karlberg J. Bmi in childhood and its association with height gain, timing of puberty, and final height. Pediatr Res. 2001;49(2):244-51.

80 Aris IM, Rifas-Shiman SL, Zhang X, Yang S, Switkowski K, Fleisch AF, et al. Association of BMI with linear growth and pubertal development. Obesity (Silver Spring). 2019;27(10): 1661-70.

81 Bideci A, Cinaz P, Hasanoglu A, Elbeg S. Serum levels of insulin-like growth factor-I and insulin-like growth factor binding protein-3 in obese children. J Pediatr Endocrinol Metab. 1997;10(3):295-9.

82 Mauras N. Growth hormone and sex steroids. Interactions in puberty. Endocrinol Metab Clin North Am. 2001;30(3):529-44.

83 Green H, Kehinde O. An established preadipose cell line and its differentiation in culture. II. Factors affecting the adipose conversion. Cell. 1975;5(1):19-27.

84 Pei Z, Yang Y, Kiess W, Sun C, Luo F. Dynamic profile and adipogenic role of growth differentiation factor 5 (GDF5) in the differentiation of 3T3-L1 preadipocytes. Arch Biochem Biophys. 2014;560:27-35.

85 Yoon BS, Pogue R, Ovchinnikov DA, Yoshii I, Mishina Y, Behringer RR, et al. BMPs regulate multiple aspects of growth-plate chondrogenesis through opposing actions on FGF pathways. Development. 2006;133(23):4667-78. 
86 Buxton P, Edwards C, Archer CW, FrancisWest P. Growth/differentiation factor-5 (GDF5) and skeletal development. J Bone Joint Surg Am. 2001;83(A Suppl 1Pt 1):S23-30.

87 Erlacher L, McCartney J, Piek E, ten Dijke P, Yanagishita M, Oppermann H, et al. Cartilage-derived morphogenetic proteins and osteogenic protein-1 differentially regulate osteogenesis. J Bone Miner Res. 1998;13(3): 383-92.

88 Chen X, Zankl A, Niroomand F, Liu Z, Katus HA, Jahn L, et al. Upregulation of ID protein by growth and differentiation factor 5 (GDF5) through a smad-dependent and MAPK-independent pathway in HUVSMC. J Mol Cell Cardiol. 2006;41(1):26-33.

89 Fujita Y, Watanabe K, Maki K. Serum leptin levels negatively correlate with trabecular bone mineral density in high-fat diet-induced obesity mice. J Musculoskelet Neuronal Interact. 2012;12(2):84-94.

90 Devlin MJ, Robbins A, Cosman MN, Moursi CA, Cloutier AM, Louis L, et al. Differential effects of high fat diet and diet-induced obesity on skeletal acquisition in female C57BL/6 J vs. FVB/NJ Mice. Bone Rep. 2018;8:204-14.

91 Zaretsky J, Griess-Fishheimer S, Travinsky T, Carmi A, Ofer L, Penn S, et al. Bone development and quality are impaired by fast food consumption in young rats. Bone Res. 2021.

92 Holmgren A, Niklasson A, Nierop AF, Gelander L, Aronson AS, Sjoberg A, et al. Pubertal height gain is inversely related to peak BMI in childhood. Pediatr Res. 2017;81(3):448-54.

93 Reinehr T, Roth CL. Is there a causal relationship between obesity and puberty? Lancet Child Adolesc Health. 2019;3(1):44-54.

94 Sandhu J, Ben-Shlomo Y, Cole TJ, Holly J, Davey Smith G. The impact of childhood body mass index on timing of puberty, adult stature and obesity: a follow-up study based on adolescent anthropometry recorded at Christ's Hospital (1936-1964). Int J Obes (Lond). 2006;30(1):14-22.

95 Schrier L, Ferns SP, Barnes KM, Emons JA, Newman EI, Nilsson O, et al. Depletion of resting zone chondrocytes during growth plate senescence. J Endocrinol. 2006;189(1): 27-36.

96 Weise M, De-Levi S, Barnes KM, Gafni RI, Abad V, Baron J. Effects of estrogen on growth plate senescence and epiphyseal fusion. Proc Natl Acad Sci USA. 2001;98(12): 6871-6.

97 Nilsson O, Weise M, Landman EB, Meyers JL, Barnes KM, Baron J. Evidence that estrogen hastens epiphyseal fusion and cessation of longitudinal bone growth by irreversibly depleting the number of resting zone progenitor cells in female rabbits. Endocrinology. 2014; 155(8):2892-9.

98 Eshet R, Maor G, Ben Ari T, Ben Eliezer M, Gat-Yablonski G, Phillip M. The aromatase inhibitor letrozole increases epiphyseal growth plate height and tibial length in peripubertal male mice. J Endocrinol. 2004; 182(1):165-72.
99 Masarwi M, Shamir R, Phillip M, GatYablonski G. Leptin stimulates aromatase in the growth plate: limiting catch-up growth efficiency. J Endocrinol. 2018;237(3):22942.

100 Turner RT, Philbrick KA, Kuah AF, Branscum AJ, Iwaniec UT. Role of estrogen receptor signaling in skeletal response to leptin in female ob/ob mice. J Endocrinol. 2017; 233(3):357-67.

101 Sopher AB, Jean AM, Zwany SK, Winston DM, Pomeranz CB, Bell JJ, et al. Bone age advancement in prepubertal children with obesity and premature adrenarche: possible potentiating factors. Obesity (Silver Spring). 2011;19(6):1259-64.

102 Brener A, Bello R, Lebenthal Y, Yackobovitch-Gavan M, Phillip M, Shalitin S. The impact of adolescent obesity on adult height. Horm Res Paediatr. 2017;88(3-4):237-43.

103 Rosario R, Agostinis-Sobrinho C, Lopes L, Moreira P, Padrao P, Oliveira A, et al. Adiposity and attained height in adolescents: a longitudinal analysis from the LabMed Physical Activity Study. J Pediatr Endocrinol Metab. 2019;32(10):1131-7.

104 Pinhas-Hamiel O, Benary D, Mazor-Aronovich $K$, Ben-Ami M, Levy-Shraga Y, Boyko V, et al. Advanced bone age and hyperinsulinemia in overweight and obese children. Endocr Pract. 2014;20(1):62-7.

105 Gibson WT, Farooqi IS, Moreau M, DePaoli AMA, Lawrence E, O'Rahilly S, et al. Congenital leptin deficiency due to homozygosity for the $\triangle 133 \mathrm{G}$ mutation: Report of another case and evaluation of response to four years of Leptin therapy. J Clin Endocrinol Metab. 2004 Oct;89(10):4821-482.

106 Farooqi IS, Wangensteen T, Collins S, Kimber W, Matarese G, Keogh JM, et al. Clinical and molecular genetic spectrum of congenital deficiency of the leptin receptor. $\mathrm{N}$ Engl J Med. 2007;356:237-47.

107 Lubrano-Berthelier C, Le Stunff C, Bougnères $\mathrm{P}$, Vaisse $\mathrm{C}$. A homozygous null mutation delineates the role of the melanocortin-4 receptor in humans. J Clin Endocrinol Metab. 2004 May;89(5):2028-32.

108 Martinelli CE, Keogh JM, Greenfield JR, Henning E, van der Klaauw AA, Blackwood A, et al. Obesity due to melanocortin 4 receptor (MC4R) deficiency is associated with increased linear growth and final height, fasting hyperinsulinemia, and incompletely suppressed growth hormone secretion. Clin Endocrinol Metab. 2011 Jan;96(1): E181-8.

109 Farooqi IS, O’Rahilly S. Monogenic obesity in humans. Annu Rev Med. 2005;56:443-58.

110 Haqq AM, Grambow SC, Muehlbauer M, Newgard CB, Svetkey LP, Carrel AL, et al. Ghrelin concentrations in Prader-Willi syndrome (PWS) infants and children: changes during development. Clin Endocrinol (Oxf). 2008;69(6):911-20.

111 Haqq AM, Muehlbauer MJ, Newgard CB, Grambow S, Freemark M. The metabolic phenotype of Prader-Willi syndrome (PWS) in childhood: heightened insulin sensitivity relative to body mass index. J Clin Endocrinol Metab. 2011;96(1):E225-32.

112 Bereket A, Kiess W, Lustig RH, Muller HL, Goldstone AP, Weiss R, et al. Hypothalamic obesity in children. Obes Rev. 2012;13(9): 780-98.

113 Holm VA, Cassidy SB, Butler MG, Hanchett JM, Greenswag LR, Whitman BY, et al. Prader-Willi syndrome: consensus diagnostic criteria. Pediatrics. 1993;91:398-402.

114 Grugni G, Crinò A, Pagani S, Meazza C, Buzi F, De Toni T, et al. Growth hormone secretory pattern in non-obese children and adolescents with Prader-Willi syndrome. J Pediatr Endocrinol Metab. 2011;24:477-81.

115 Aycan Z, Baş VN. Prader-Willi syndrome and growth hormone deficiency. J Clin Res Pediatr Endocrinol. 2014;6(2):62-7.

116 Guo D, Rahmouni K. Molecular basis of the obesity associated with Bardet-Biedl syndrome. Trends Endocrinol Metab. 2011; 22(7):286-93

117 Feuillan PP, Ng D, Han JC, Sapp JC, Wetsch $\mathrm{K}$, Spaulding E, et al. Patients with BardetBiedl syndrome have hyperleptinemia suggestive of Leptin resistance. J Clin Endocrinol Metab. 2011 Mar;96(3):E528-35.

118 Perry JR, Day F, Elks CE, Sulem P, Thompson DJ, Ferreira T, et al. Parent-of-originspecific allelic associations among 106 genomic loci for age at menarche. Nature. 2014;514(7520):92-7.

119 Frisch RE, McArthur JW. Menstrual cycles: fatness as a determinant of minimum weight for height necessary for their maintenance or onset. Science. 1974;185(4155):949-51.

120 Elias CF, Purohit D. Leptin signaling and circuits in puberty and fertility. Cell Mol Life Sci. 2013;70(5):841-62.

121 Tomlinson JW, Stewart PM. The functional consequences of 11beta-hydroxysteroid dehydrogenase expression in adipose tissue. Horm Metab Res. 2002;34(11-12):746-51.

122 Belanger C, Luu-The V, Dupont P, Tchernof A. Adipose tissue intracrinology: potential importance of local androgen/estrogen metabolism in the regulation of adiposity. Horm Metab Res. 2002;34(11-12): $737-45$.

123 Navarro VM, Tena-Sempere M. Neuroendocrine control by kisspeptins: role in metabolic regulation of fertility. Nat Rev Endocrinol. 2011;8(1):40-53.

124 Sanchez-Garrido MA, Ruiz-Pino F, Manfredi-Lozano M, Leon S, Garcia-Galiano D, Castano JP, et al. Obesity-induced hypogonadism in the male: premature reproductive neuroendocrine senescence and contribution of Kiss1-mediated mechanisms. Endocrinology. 2014;155(3):1067-79.

125 Vazquez MJ, Velasco I, Tena-Sempere M. Novel mechanisms for the metabolic control of puberty: implications for pubertal alterations in early-onset obesity and malnutrition. J Endocrinol. 2019;242(2):R51-65. 
126 Lebrethon MC, Vandersmissen E, Gerard A, Parent AS, Junien JL, Bourguignon JP. In vitro stimulation of the prepubertal rat gonadotropin-releasing hormone pulse generator by leptin and neuropeptide $Y$ through distinct mechanisms. Endocrinology. 2000; 141(4):1464-9.

127 Rutters F, Nieuwenhuizen AG, Verhoef SP, Lemmens SG, Vogels N, Westerterp-Plantenga MS. The relationship between leptin, gonadotropic hormones, and body composition during puberty in a Dutch children cohort. Eur J Endocrinol. 2009;160(6):9738.

128 Roemmich JN, Clark PA, Berr SS, Mai V, Mantzoros CS, Flier JS, et al. Gender differences in leptin levels during puberty are related to the subcutaneous fat depot and sex steroids. Am J Physiol. 1998;275(3):E54351.

129 Bianco SD. A potential mechanism for the sexual dimorphism in the onset of puberty and incidence of idiopathic central precocious puberty in children: sex-specific kisspeptin as an integrator of puberty signals. Front Endocrinol (Lausanne). 2012;3:149.

130 Jin L, Burguera BG, Couce ME, Scheithauer BW, Lamsan J, Eberhardt NL, et al. Leptin and leptin receptor expression in normal and neoplastic human pituitary: evidence of a regulatory role for leptin on pituitary cell proliferation. J Clin Endocrinol Metab. 1999;84(8):2903-11.

131 Yu WH, Kimura M, Walczewska A, Karanth S, McCann SM. Role of leptin in hypothalamic-pituitary function. Proc Natl Acad Sci USA. 1997;94(3):1023-8.

132 Karlsson C, Lindell K, Svensson E, Bergh C, Lind P, Billig H, et al. Expression of functional leptin receptors in the human ovary. J Clin Endocrinol Metab. 1997;82(12):41448.

133 Caprio M, Isidori AM, Carta AR, Moretti C, Dufau ML, Fabbri A. Expression of functional leptin receptors in rodent Leydig cells. Endocrinology. 1999;140(11):4939-47.

134 Plant TM, Shahab M. Neuroendocrine mechanisms that delay and initiate puberty in higher primates. Physiol Behav. 2002; 77(4-5):717-22.

135 El Majdoubi M, Sahu A, Ramaswamy S, Plant TM, Neuropeptide Y. Neuropeptide Y: a hypothalamic brake restraining the onset of puberty in primates. Proc Natl Acad Sci USA. 2000;97(11):6179-84.

136 Barkan D, Jia H, Dantes A, Vardimon L, Amsterdam A, Rubinstein M. Leptin modulates the glucocorticoid-induced ovarian steroidogenesis. Endocrinology. 1999; 140(4):1731-8.

137 Smith CP, Dunger DB, Williams AJ, Taylor AM, Perry LA, Gale EA, et al. Relationship between insulin, insulin-like growth factor I, and dehydroepiandrosterone sulfate concentrations during childhood, puberty, and adult life. J Clin Endocrinol Metab. 1989; 68(5):932-7.
138 Biason-Lauber A, Zachmann M, Schoenle EJ. Effect of leptin on CYP17 enzymatic activities in human adrenal cells: new insight in the onset of adrenarche. Endocrinology. 2000;141(4):1446-54.

139 Genazzani AR, Pintor C, Corda R. Plasma levels of gonadotropins, prolactin, thyroxine, and adrenal and gonadal steroids in obese prepubertal girls. J Clin Endocrinol Metab. 1978;47(5):974-9.

140 Dobrzyn K, Smolinska N, Kiezun M, Szeszko K, Rytelewska E, Kisielewska K, et al. Adiponectin: a new regulator of female reproductive system. Int J Endocrinol. 2018;2018: 7965071.

141 Mathew H, Castracane VD, Mantzoros C. Adipose tissue and reproductive health. $\mathrm{Me}$ tabolism. 2018;86:18-32.

142 Sitticharoon C, Sukharomana M, Likitmaskul S, Churintaraphan M, Maikaew P. Corrigendum to: Increased high molecular weight adiponectin, but decreased total adiponectin and kisspeptin, in central precocious puberty compared with aged-matched prepubertal girls. Reprod Fertil Dev. 2017; 29(12):2506.

143 Gamba M, Pralong FP. Control of GnRH neuronal activity by metabolic factors: the role of leptin and insulin. Mol Cell Endocrinol. 2006;254-255:133-9.

144 Burcelin R, Thorens B, Glauser M, Gaillard RC, Pralong FP. Gonadotropin-releasing hormone secretion from hypothalamic neurons: stimulation by insulin and potentiation by leptin. Endocrinology. 2003;144(10): 4484-91.

145 Ibanez L, Diaz R, Lopez-Bermejo A, Marcos MV. Clinical spectrum of premature pubarche: links to metabolic syndrome and ovarian hyperandrogenism. Rev Endocr Metab Disord. 2009;10(1):63-76.

146 Thankamony A, Ong KK, Ahmed ML, Ness AR, Holly JM, Dunger DB. Higher levels of IGF-I and adrenal androgens at age 8 years are associated with earlier age at menarche in girls. J Clin Endocrinol Metab. 2012; 97(5):E786-90.

147 l'Allemand D, Schmidt S, Rousson V, Brabant G, Gasser T, Gruters A. Associations between body mass, leptin, IGF-I and circulating adrenal androgens in children with obesity and premature adrenarche. Eur J Endocrinol. 2002;146(4):537-43.

148 McCartney CR, Blank SK, Prendergast KA, Chhabra S, Eagleson CA, Helm KD, et al. Obesity and sex steroid changes across puberty: evidence for marked hyperandrogenemia in pre- and early pubertal obese girls. J Clin Endocrinol Metab. 2007;92(2):430-6.

149 Cizza G, Dorn LD, Lotsikas A, Sereika S, Rotenstein D, Chrousos GP. Circulating plasma leptin and IGF-1 levels in girls with premature adrenarche: potential implications of a preliminary study. Horm Metab Res. 2001;33(3):138-43.

150 Blank SK, McCartney CR, Chhabra S, Helm $\mathrm{KD}$, Eagleson CA, Chang RJ, et al. Modula- tion of gonadotropin-releasing hormone pulse generator sensitivity to progesterone inhibition in hyperandrogenic adolescent girls-implications for regulation of pubertal maturation. J Clin Endocrinol Metab. 2009; 94(7):2360-6.

151 Kinyua AW, Doan KV, Yang DJ, Huynh MKQ, Choi YH, Shin DM, et al. Insulin regulates adrenal steroidogenesis by stabilizing SF-1 activity. Sci Rep. 2018;8:5025.

152 Bélanger C, Luu-The V, Dupont P, Tchernof A. Adipose tissue intracrinology: potential importance of local androgen/estrogen metabolism in the regulation of adiposity. Horm Metab Res. Nov-Dec 2002;34(11-12):737-45.

153 Tomlinson JW, Finney J, Gay C, Hughes BA, Hughes SV, Stewart PM. Impaired glucose tolerance and insulin resistance are associated with increased adipose 11beta-hydroxysteroid dehydrogenase type 1 expression and elevated hepatic 5alpha-reductase activity. Diabetes. 2008;57:2652-60.

154 Gawlik AM, Shmoish M, Hartmann MF, udy SA, Hochberg Z. Steroid metabolomic signature of insulin resistance in childhood obesity. Diabetes Care. 2020 Feb;43(2):40510.

155 Martos-Moreno GA, Chowen JA, Argente J. Metabolic signals in human puberty: effects of over and undernutrition. Mol Cell Endocrinol. 2010;324(1-2):70-81.

156 Kaplowitz PB, Slora EJ, Wasserman RC, Pedlow SE, Herman-Giddens ME. Earlier onset of puberty in girls: relation to increased body mass index and race. Pediatrics. 2001;108(2):347-53.

157 Aksglaede L, Sorensen K, Petersen JH, Skakkebaek NE, Juul A. Recent decline in age at breast development: the Copenhagen $\mathrm{Pu}$ berty Study. Pediatrics. 2009;123(5):e932-9.

158 Biro FM, Greenspan LC, Galvez MP, Pinney SM, Teitelbaum S, Windham GC, et al. Onset of breast development in a longitudinal cohort. Pediatrics. 2013;132(6):1019-27.

159 Ong KK, Emmett P, Northstone K, Golding J, Rogers I, Ness AR, et al. Infancy weight gain predicts childhood body fat and age at menarche in girls. J Clin Endocrinol Metab. 2009;94(5):1527-32.

160 Juul A, Magnusdottir S, Scheike T, Prytz S, Skakkebaek NE. Age at voice break in Danish boys: effects of pre-pubertal body mass index and secular trend. Int J Androl. 2007; 30(6):537-42.

161 Busch AS, Hollis B, Day FR, Sorensen K, Aksglaede L, Perry JRB, et al. Voice break in boys-temporal relations with other pubertal milestones and likely causal effects of BMI. Hum Reprod. 2019;34(8):1514-22.

162 Lee JM, Wasserman R, Kaciroti N, Gebremariam A, Steffes J, Dowshen S, et al. Timing of puberty in overweight versus obese boys. Pediatrics. 2016;137(2):e20150164.

163 Busch AS, Hojgaard B, Hagen CP, Teilmann G. Obesity is associated with earlier pubertal onset in boys. J Clin Endocrinol Metab. 2020;105(4). 
164 Herman-Giddens ME, Steffes J, Harris D, Slora E, Hussey M, Dowshen SA, et al. Secondary sexual characteristics in boys: data from the Pediatric Research in Office Settings Network. Pediatrics. 2012;130(5): e1058-68.

165 Stokes VJ, Anderson RA, George JT. How does obesity affect fertility in men - and what are the treatment options?. Clin Endocrinol (Oxf). 2015;82(5):633-8.

166 Wagner IV, Yango P, Svechnikov K, Tran $\mathrm{ND}$, Soder O. Adipocytokines may delay pubertal maturation of human Sertoli cells. Reprod Fertil Dev. 2019.
167 Parent AS, Franssen D, Fudvoye J, Pinson A, Bourguignon JP. Current changes in pubertal timing: revised vision in relation with environmental factors including endocrine disruptors. Endocr Dev. 2016;29:174-84.

168 Berkey CS, Gardner JD, Frazier AL, Colditz GA. Relation of childhood diet and body size to menarche and adolescent growth in girls. Am J Epidemiol. 2000;152(5):446-52.

169 Jansen EC, Marin C, Mora-Plazas M, Villamor E. Higher childhood red meat intake frequency is associated with earlier age at Menarche. J Nutr. 2015;146(4):792-8.
170 Gunther AL, Karaolis-Danckert N, Kroke A, Remer T, Buyken AE. Dietary protein intake throughout childhood is associated with the timing of puberty. J Nutr. 2010;140(3):56571.

171 Lee JE, Jung HW, Lee YJ, Lee YA. Early-life exposure to endocrine-disrupting chemicals and pubertal development in girls. Ann Pediatr Endocrinol Metab. 2019;24(2):78-91.

172 Tassinari R, Tait S, Busani L, Martinelli A, Narciso L, Valeri M, et al. Metabolic, reproductive and thyroid effects of bis(2-ethylhexyl) phthalate (DEHP) orally administered to male and female juvenile rats at dose levels derived from children biomonitoring study. Toxicology. 2021 Feb 15;449:152653. 